\title{
Between Economy and Security. Dilemmas of Sustainable Development in the Covid-19 Era - an Example of Great Britain
}

\author{
Między ekonomią a bezpieczeństwem. Dylematy \\ zrównoważonego rozwoju w erze koronawirusa - \\ przykład Wielkiej Brytanii
}

\author{
Paweł Rydzewski \\ Institute of Sociology, Faculty of Philosophy and Sociology \\ Maria Curie-Sktodowska University in Lublin, Poland \\ E-mail: p.rydzewski@umcs.pl \\ Researcher ID: A-1562-2019, ORCID: 0000-0002-8144-6340
}

\begin{abstract}
The coronavirus Covid-19 pandemic has disrupted social stability in many countries around the world. This has consequences for sustainable development. In a situation of stability, two competing pillars of sustainable development: the economic and the environmental one, are in the lead - as long as the basic needs of most people are satisfied. In the conditions of instability, the social pillar begins to dominate, pushing the economic and environmental pillars to the background. The fight against the pandemic is or has been carried out in different countries in different ways. We can talk about the Chinese, Taiwanese, or European models, among others. In the United Kingdom, the laissez-faire model was used for a short time. This was an interesting strategy (though a very risky one) that attempted to reconcile different pillars of sustainable development in the face of crisis, seeking a compromise between health considerations, social situation, and the requirements of the economy. However, this approach was quickly rejected under the influence of public opinion, the media and scientific authorities. In the situation of impending crisis, the social pillar began to dominate. The dilemma economy vs. security was resolved according to the hierarchy of needs (with security being a more basic need). This is a tip for the future - for social policy and planning in times of stability. In a situation of deep biological crisis (as opposed to economic crises), the social factor comes to the fore in the end, at the expense of all others. Within the social factor, the hierarchy of goals will be established according to the hierarchy of needs.
\end{abstract}

Key words: coronavirus, Covid-19, epidemic, pandemic, Wuhan, Great Britain, China, Taiwan, security

\section{Streszczenie}

Pandemia koronawirusa zaburzyła stabilizację społeczną w wielu krajach świata. Ma to konsekwencje dla zrównoważonego rozwoju. W warunkach stabilizacji prym wiodą konkurujące ze sobą filary rozwoju zrównoważonego: ekonomiczny i środowiskowy - o ile zaspokojone są podstawowe potrzeby większości społeczeństwa. W warunkach braku stabilizacji zaczyna dominować filar społeczny spychając filar ekonomiczny i w jeszcze większym stopniu środowiskowy na plan dalszy. Walka z pandemią przebiega lub przebiegła w różnych krajach w różny sposób. Można mówić o modelu chińskim, tajwańskim, europejskim, itp. W Wielkiej Brytanii przez krótki czas postawiono na model liberalny. Był ciekawą propozycją (choć bardzo ryzykowną), pogodzenia filarów zrównoważonego rozwoju w obliczu kryzysu, szukania kompromisu między względami zdrowotnymi, sytuacja społeczną i wymogami gospodarki. Został on jednak dość szybko odrzucony pod wpływem opinii publicznej, mediów i autorytetów naukowych. W sytuacji nadciągającego kryzysu dominować zaczął filar społeczny. Dylemat ekonomia vs. bezpieczeństwo został rozwiązany zgodnie z hierarchią potrzeb (potrzebą bardziej podstawową jest 
bezpieczeństwo). To wskazówka na przyszłość - dla polityki społecznej i planowania w czasach stabilizacji. W sytuacji głębokiego kryzysu o źródłach biologicznych (w odróżnieniu od kryzysów ekonomicznych) w ostatecznym rachunku dochodzi do głosu przede wszystkim czynnik społeczny, kosztem wszystkich innych. Zaś w obrębie czynnika społecznego hierarchia celów zostanie ustanowiona zgodnie z hierarchią potrzeb.

Słowa kluczowe: koronawirus, Covid-19, epidemia, pandemia, Wuhan, Wielka Brytania, Chiny, Tajwan, bezpieczeństwo

\section{Introduction}

On 31 January 2020, two members of a family of Chinese nationals staying in a hotel in York, became the first confirmed cases of Covid-19 in the UK. Upon confirmation, they were transferred from Hull University hospital to the specialist Infectious Diseases Unit in Newcastle. On 5 March, the total number of confirmed cases in the UK exceeded 100, on 15 March - it reached almost 1400, and on 20 March - almost 4000, with most cases recorded in London and in the central part of the country.

The growth in the number of infected people during the first week (measured from the day when the number of cases exceeded 100) was relatively low (460) - lower than in Germany (800), France (653), Spain $(674)$, let alone Italy $(1,128)$. However, in absolute numbers it reached 5,000 cases fairly quickly (after another 10 days).

The measures adopted by the UK government gave rise to widespread discussion on whether the British approach to handling the disease was appropriate. The reason was that the strategy proposed by the British government was not typical and differed significantly from the one adopted in Asia or from the measures that were being (or had been) taken by other European governments at that time. After some time, pressed by the public opinion, the UK government changed its strategy, adopting standards used by most other European countries.

This situation and in particular the radical change of the strategy to suppress the spread of the epidemic, is an extremely interesting issue that can be considered from the perspective of dilemmas of achieving sustainable development goals.

\section{Health and security as sustainable development goals}

The social environment (customs, culture, spirituality, interpersonal relationships, and living conditions) can become degraded just as the natural environment can. It is worth remembering that the social environment should ensure the basis for an individual's existence (Pawłowski, 2008).

The International Covenant on Economic, Social and Cultural Rights states that the enjoyment of the highest attainable standard of health is one of the funda-

\footnotetext{
${ }^{1}$ Data based on www.worldometers.info. At the time when the article was submitted for publication, the number of
}

mental rights of every human being regardless of their race, religion, political beliefs, economic or social conditions. The full enjoyment of the right to health is critical for the enjoyment of other human rights. Good health is thus an end in itself and plays an integral role in the development of human capabilities and the well-being of society. Health is central to all three pillars of sustainable development, as it is the beneficiary of and contributor to development. It should be noted that health is a value in itself, but it is also an integral part of human well-being. In order to protect and promote public health, it is necessary to take into account the health implications of policies and programmes in all sectors, for example in energy, transport, agriculture, and as part of broader policies concerning labour rights, trade liberalization, intellectual property and environmental protection, among others. Health can therefore serve as an indicator of whether development and sector policies benefit individuals and their families in ways that are tangible and easily understood (TST Issue Brief ..., 2014).

Health is therefore an important input to sustainable development. Without health, there is no sustainable development; healthy people are better able to learn, work and contribute positively to their economies and societies (Health, Environment ..., 2013).

Health can be considered in individual terms and also in group terms when we deal with the mass threat to health and life. In the latter case, health is very closely related to a sense of security in the macro-social dimension. One of the goals of sustainable development is peace and order, which means that communities coexist peacefully and protect their members from crime and violence (Prescott-Allen, 2001). However, this goal can be understood more broadly as the freedom from feeling threatened also by an epidemic or pandemic. Both have a common foundation, which is the fear that reduces the quality of life, fear for one's own health and life and for the health and life of close friends and relatives. It should also be mentioned that a pandemic in its extreme form leads to crime, as it was for example during the influenza pandemic after World War I.

Let us now take a closer look at the issue of security. Society can survive on its own when the conditions are favourable, but we speak about the security of society only when it is ensured by the state. There is

coronavirus cases in Great Britain stood at 206 715. Fatalities included 30615 persons (7.05.2020). 
no organizational structure to ensure the security of the human species, hence one cannot speak about the security of the human species. On the other hand, when we refer to public security, we mean the security of some society living in a state, not of any society, for example one that lives in an anarchy (Skarzyński, 2017).

Security can also be viewed as the need to ensure physical security for oneself and one's relatives and friends, and to satisfy basic material needs, such as food, home, etc. (Wolska-Zogata, 2018). When this need is not fulfilled, it is damaging for an individual or a group, as it destabilises their functioning. This motivates individuals to resist adverse changes and use protective measures to restore their sense of security (Kukułka, 1995).

Security is most commonly associated with the alleviation of threats to cherished values and therefore it is best understood as survival plus, the plus being some freedom from life-determining threats. To simplify, it is possible to identify two prevalent ways of understanding security. This distinction is commonly reflected in the ideas of freedom from and freedom to (Williams, 2008). Thus, in relation to a pandemic, it is the freedom from the risk of getting ill or dying, and freedom (right) to maintain life and health.

How is the threat to security (in this case, in the face of the pandemic) connected with sustainable development? Firstly, the spread of the disease poses a direct threat to the health of people, which is to be protected by the state, and for the first time in perhaps half a century, this includes the populations of Western states. Secondly, a pandemic may cause social disruption and threaten the stability of a state: confidence in the state may be reduced if it cannot provide a basic level of protection against disease; social inequalities may be highlighted as the rich or privileged have access to better drugs or healthcare, potentially leading to public disorder; if many people die or are unable to work, public services may be placed at risk, threatening the functioning of a state; violence may appear if the authorities become unable to cope and if groups feel they have nothing to lose. In this way, a state may begin to fail, threatening its own security. Thirdly, a large-scale epidemic may also bring about economic downturn by: forcing increased government spending on health as a percentage of GDP; reducing productivity due to worker absenteeism and the loss of skilled personnel; reducing investment (internal and external) due to a lack of business confidence. For the state involved, the costs may be very significant, and in a globalized world the effects may be felt worldwide. The macroeconomic effects of a pandemic may therefore be very significant, which in turn will affect the ability of states to ensure their citizens safety and well-being (McInnes, 2008).

\section{Models of handling the coronavirus Covid-19 ep- idemic}

The outbreak of the coronavirus Covid-19 in Asia met with a very decisive response from many governments and very disciplined behaviour of citizens. Asian countries quickly decided to introduce severe travel restrictions. Moreover, they started to build modern hospitals with isolation units, produce face masks on a mass-scale, and use advanced technology to minimize losses. Model measures were implemented by Taiwan. Let us enumerate them in a chronological order, focusing only on those taken at the early stages, as time was of great importance here:

- 31 December 2019 - mass screenings of passengers coming on inbound flights from Wuhan began;

- 23 January 2020 - ban on entering Taiwan;

- 24 January 2020 - export of surgical masks was suspended and the government requested the private sector to increase production;

- 25 January 2020 - travels to China were suspended;

- 31 January 2020 - the private sector was banned from hoarding supplies and using exploitative pricing;

- 6 February 2020 - Chinese citizens were banned from entering Taiwan; a new purchasing policy was introduced to facilitate the purchase of scarce goods (especially face masks) and to prevent people from making mass purchases.

Moreover, Taiwan promptly set up a unified command centre, led by the Ministry of Health and Welfare, to manage resources, hold daily briefings, and inform the public. The cases were mapped to show the sources of infection, the media campaign was launched to educate the public on the risks of the disease and precautions to take, and data was used for analysis and developing platforms to inform people where masks were currently available and where the infected people had been.

It is worth emphasising that Taiwan introduced a travel ban very early (from the beginning of February), and this ban is effective only if introduced at the outset of an epidemic. The Taiwanese model can be called a radical one.

In China, the preventive measures of this type were implemented too late. Also other countries reacted too slowly: South Korea banned its citizens from travelling but as long as until March this ban concerned only the Chinese province of Hubei; Japan banned visitors from Hubei and Zhejiang and suspended visas for the Chinese on 9 March 2020, and Chinese tourists already in the territory of Japan were required to quarantine for two weeks. As a re- 
sult, South Korea and Japan were not as successful as Taiwan in combating the spread of the coronavirus Covid-19. Measures similar to the ones in Taiwan were also introduced in Macau and Singapore. In general, the response of the authorities in Asia was relatively speedy and radical, and most often met with social approval (it should be remembered that these were the first experiences with the coronavirus Covid-19 and it was not known yet whether an epidemic or pandemic would break out).

Europe failed to implement the radical strategy. This failure was mostly due to the delays in introducing restrictions, sometimes it resulted from inconsistent actions or long-standing problems in the healthcare system. It was not only the policy of governments that did not pursue the radical approach, but also the behaviour of many societies. Another thing is that the dynamics of the virus in Europe was different from country to country. Certainly, the Taiwanese approach to coping with the coronavirus Covid-19 stands in stark contrast to the Italian approach, which was characterized by disregarding the threat, delayed government actions, and lack of discipline on the part of Italian society. Learning from the Italian experience, other European countries such as Germany, France and Spain attempted to introduce restrictions and other measures to limit the spread of the virus but these actions were taken too late and lacked the determination typical of the Taiwanese model. Some European countries (for example, Poland, the Czech Republic, or Slovakia) were in a better position, as the virus appeared there later. Consequently, they could learn from the mistakes of those that had been hit by the epidemic earlier, and take more stringent action earlier and with more understanding on the part of their societies.

It would seem, therefore, that one can speak of two policies regarding the pandemic: the radical policy on the one hand, and all those that differ - to a lesser or greater extent - from it, on the other hand. This contradistinction, however, is only apparent. In fact, there is just one policy modelled on the Taiwanese approach. The difference is whether this policy was implemented almost in its entirety (as in Taiwan), in a form close to it (as in China), in different forms but with the same goal (as in most European countries), or in a completely unsuccessful way (as in Italy). In fact, the aim had always been the same, but in some countries it was achieved and the radical model was implemented, while in others the measures were not so successful, or they failed completely.

The goal was to win the battle against the virus by introducing (sooner or later) specific measures, such as restrictions on the movement of people, social distancing, isolating places that were the focal points of the coronavirus Covid-19 outbreak, etc.

As far as the ways (not goals) are concerned, three approaches to fighting the coronavirus Covid-19 can be distinguished. The first is the Chinese model eradicating the disease to zero: complete paralysis of life in the infected zone, significant restrictions on freedoms in other places, isolating the sick, and controlling the movement of people. The Chinese model, which turned out to be quite effective, cannot be replicated in Europe, not only for cultural and political reasons (society is much less disciplined), but also because European states do not exercise such strict control over their citizens. The second model, chronologically speaking, is the Taiwanese one, which has been described above. The third, European model is based on restricting large sections of economic and social life, including closing schools, self-isolation, etc. Slowing down the number of cases and extending the epidemic in time will probably lead to overloading the capacity of intensive care units and huge economic costs. The real threat of a deep economic recession can be seen.

\section{British laissez-faire model}

Britain's approach was different from that of other countries, but eventually it was abandoned under the pressure from public opinion and the media. Originally, the British model assumed lower economic losses, but greater social costs, in particular: (a) high mortality and acceptance of high fatality rates (breach of social solidarity), (b) psychological losses - intensified panic, (c) a large margin of uncertainty as to the effectiveness of actions taken and sacrifices to be made.

Professor Ian Donald, a psychologist at the University of Liverpool, explained the assumptions of the UK's government by stating that they were potentially very effective but much more risky than those adopted by most European countries. The government assumption was that up to $80 \%$ of the population in the UK would become infected no matter what measures were taken. So since it was impossible to stop infections, more emphasis should be placed on treating the sick. Great Britain wanted to stop the coronavirus Covid-19 infection, but only in the group of people at higher risk of health complications. Having many lower risk people infected would be beneficial because it would increase the overall immunity to this disease in society. This explains why schools were not closed in the initial stage of the epidemic. However, this approach is quite risky, as it may turn out that the number of infected people that require hospitalization will exceed the National Health System capacity. The key, therefore, would be to minimize the risk of infection for those for whom the virus may be fatal. Thus elderly people were to be quarantined for up to several months at home or in senior centres. They would have food and medicines delivered free of charge. The rest of society would be subject to only necessary restrictions to prevent the rise in infection rate. They would work or go to schools as normally as possible. This model focused on saving the country's economy (Donald, 2020). 
In mid-March 2020, the Guardian published fragments of a British government secret report. It revealed that (a) the epidemic would last until spring 2021 , (b) up to half a million Britons could die at that time, (c) in the worst-case scenario almost 8 million people may require hospitalization, (d) an estimated number of people that may die at that time was between 300,000 and 500,000, (e) the peak of the epidemic was forecast for the turn of April and May, then the situation would calm down slightly, but the virus would resurge in November (The Guardian, 2020).

The document prepared by the government agency Public Health England detailed how the healthcare system was not prepared for an epidemic of this scale. One of the problems was lack of medical equipment. Great Britain had far too few ventilators needed to control such a widespread epidemic. If in fact $80 \%$ of the British people were infected with the virus, that would mean over 50 million sick people. Assuming optimistically that the mortality rate is at $1 \%$ only, that would still mean that 500,000 people in Great Britain could die in one year (Health \& Social ..., 2020).

Despite that, the UK government decided that more radical measures might be implemented at some later stage, as introducing them too early could result in British people ignoring the new rules, which in turn would weaken the government's ability to keep the situation under control. According to government experts, the epidemic would not reach its peak in the UK in many weeks, and by that time people might stop complying with the regulations. According to government officials, the ban on organizing mass events would be pointless at this stage. On the other hand, severe restrictions would seriously affect the labour market and economy.

This policy of the British government met with public opposition. Over 229 scientists wrote an open letter to the government calling for stricter measures to prevent the spread of the disease (Public Request ..., 2020). The signatories believed that the UK's approach would put NHS at an even stronger level of stress, risking many more lives than necessary. They also criticised the comments made by Sir Patrick Vallance, the government's chief scientific adviser, about managing the spread of the infection to make the population immune, and questioned the view that people would become fed up with restrictions if they were imposed too soon. In the open letter, the group of scientists argued that stronger social distancing measures would dramatically slow the rate of growth of the disease in the UK, and would spare thousands of lives. The group specializing in many disciplines ranging from mathematics to genetics stated that the current measures were insufficient and additional and more restrictive measures should be taken immediately, as was happening in other countries. In the open letter, the scientists wrote: Going for 'herd immunity' at this point does not seem a vi- able option. They concluded that radical behaviour change could have a much better effect and could save very large numbers of lives (BBC News, 2020). According to Professor Willem van Schaik from Birmingham University, the major downside of herd immunity is that this will mean that in the UK alone at least 36 million people will need to be infected and recover. He believes that it is almost impossible to predict what that will mean in terms of human costs, but we are conservatively looking at tens of thousands of deaths, and possibly at hundreds of thousands of deaths. Professor van Schaik also notes that the UK is the only country in Europe that is following what he describes as its laissez-faire attitude to the virus (BBS News, 2020).

A report released by Imperial College was another important voice in the discussion. It stated that epidemic suppression was the only viable strategy currently, although the social and economic effects of the measures which were needed to achieve this policy goal would be profound. It also noted that many countries had already adopted such measures, but even those countries at an earlier stage of their epidemic (such as the UK) would need to do so immediately (Ferguson et al. 2020).

The British society could express their opinion on this matter in social surveys. Opinium interviewed 2,005 adults from the UK on 12-13 March 2020. The surveys show that $44 \%$ of the British considered closing schools to be necessary, $73 \%$ believed that work from home was necessary, $73 \%$ were worried about the coronavirus Covid- 19 (with $23 \%$ very worried), and $41 \%$ believed that the government was not doing enough in the way it was handling the pandemic. These numbers show that the UK government did not have sufficient public support for its radically liberal policy towards the virus (Opinion, 2020).

\section{Retreat from the laissez-faire model}

Faced with new information, as well as harsh criticism coming from scientists and the media, the British government gave up the laissez-fair strategy for fighting the pandemic, and on 20 March ordered to shut down all pubs, clubs, restaurants, cinemas, museums, gyms and leisure centres as soon as possible, in order to stop the spread of the coronavirus Covid19. At the same time, it announced another package of support for the economy, which aimed primarily to save jobs. Prime Minister Boris Johnson explained that it was necessary to step up the fight against the coronavirus. He announced that compliance with new regulations would be rigorously monitored and businesses failing to comply would risk the loss of licence. Three days later, further restrictions were introduced: British people were only allowed to leave their home for shopping, medical needs, travelling to and from work, but only where this was absolutely necessary and could not be done from home, and for 
one form of exercise a day - for example a walk or outdoor workout. On Monday, the UK Foreign Office urged all British citizens on holiday or on business trips abroad to return home immediately, while they still had that opportunity. In this way, Great Britain joined the countries actively combatting the coronavirus Covid-19 epidemic. However, this was done too late.

Anthony Costello, a doctor and researcher associated with University College London and the World Health Organization, publicly asked why the UK Prime Minister was taking decisive steps so late. Costello wondered whether this resulted from the influence of a group of government advisors led by clinical scientists with no experience in controlling large-scale epidemics, or perhaps from the British sense of uniqueness and disregard for the Chinese and Korean experience with the pandemic (Costello, 2020).

The fact is, however, that Britain changed its strategy to the European one, with all its consequences - both positive and negative.

\section{Implications for sustainable development}

It can be assumed, although it is a somewhat simplified assumption, that in a situation of social stability and as long as the basic needs of most people are satisfied, two competing pillars of sustainable development are in the lead: the economic and the environmental one. When a situation becomes unstable, the social pillar begins to dominate, and pushes economy and environment to the background (with environment being less important than the economy). One might even ask whether speaking about sustainable development in the period of destabilization still makes sense This question is certainly justified when destabilization is deep and lasts for a long time. However, in its initial stage - which we experienced in March 2020 - a link with the idea of sustainable development has not yet been cut. For example, as far as the economy is concerned, the hope for growth (even a very weak one) has not yet been completely overshadowed by the vision of recession (although there is a growing pessimism). In this extremely important stage, key decisions in the field of epidemiology, economy, social policy and law were made, setting out further directions for how the situation would develop.

The rejection of the British model is crucial here. The attempt to reconcile different pillars of sustainable development in the face of crisis, seeking a compromise between health considerations, social situation and the economy (with the environmental pillar being in a state of constans), ended in a fiasco. With an impending crisis, the social pillar began to dominate. It is worth noting that this can be compared to a revolution devouring its own children. Determined protection of social goals (health, house- holds and household incomes) must bring about lowering of the quality of life in the future. So the hierarchy of needs had the final say in the end, with basic and more immediate needs coming to the fore.

From the perspective of sustainable development, this is a dilemma that is difficult to solve and it does not only concern the long-known conflict between the requirements of economic growth and social goals, or between the economy and the environment. We are faced with a completely new dilemma within one pillar - the social one; i.e., is it more important to meet immediate needs (with high costs for the future), or is a long-time perspective more important, even at the cost of making sacrifices today? To refer to the situation of the pandemic: is it more important to protect the health and life of all members of society even if this means lower quality of life in the future, or perhaps it is better to take the risk of bearing social costs today so that the quality of life in the future will not deteriorate dramatically.

This dilemma, as mentioned above, was solved in accordance with the hierarchy of needs, which may be a tip for the future - for social policy and planning in times of stability. In the situation of deep biological crisis (as opposed to economic crises), the social factor will ultimately have the final word at the expense of all other factors. Within the social pillar, the hierarchy of goals will be based on the hierarchy of needs (with basic needs at the top).

\section{References}

1. BBC NEWS, 2020, Coronavirus: Some scientists say UK virus strategy is 'risking lives', https://www.bbc com/news/science-environment-51892402 (14.03. 2020).

2. COSTELLO A., 2020, Unlike all other countries, the UK strategy aims to build herd immunity by allowing the steady spread of \#COVID19, Twitter (13.03.2020).

3. DONALD I., 2020, The Government Strategy on Coronavirus..., Twitter, https://twitter.com/iandona ld_psych/status/1238518371651649538 (13.03. 2020).

4. FERGUSON N.M., 2020, Impact of non-pharmaceutical interventions (NPIs) to reduce COVID- 19 mortality and healthcare demand, Imperial College London, p. 16.

5. Health, Environment and Sustainable Development: Towards the Future We Want. A collection of texts based on the PAHO Seminar Series towards Rio+20 that occurred in the period between 8 February and 13 June 2012, Pan American Health Organization, p. 2.

6. HEALTH \& SOCIAL CARE DEPT. 2020, Coronavirus Action Plan. A guide to what you can expect across the UK, 3 March.

7. KUKUŁKA J., 1995, Nowe uwarunkowania i wymiary bezpieczeństwa międzynarodowego Polski, in: Wieś i Państwo, 1, p. 198-199.

8. MCINNES C., 2008, Health, in: Security Studies. An Introduction, ed. Williams P.D., Routledge, London New York, p. 276-279. 
9. OPINIUM, 2020, The Political Report, 12th March 2020, p. 3-4.

10. PAWŁOWSKI A, 2008, How many dimensions does sustainable development have?, in: Sustainable Development, 16(2), p. 81-90.

11. PRESCOTT-ALLEN R., 2001, The Wellbeing of Nations. A Country-by-Country Index of Quality of Life and the Environment, Island Press, Washington, Covelo, London, p. 13-14.

12. Public request to take stronger measures of social distancing across the UK with immediate effect, 2020, http://maths.qmul.ac.uk/ vnicosia/UK_scientists_statement_on_coronavirus_measures.pdf (14.03.2020).

13. SKARZYŃSKI R., E. KUŻELEWSKA, 2017, Bezpieczeństwo jako zjawisko społeczne, in: Środkowoeuropejskie Studia Polityczne, 2, p. 22-23.
14. THE GUARDIAN, 2020, UK Coronavirus Crisis 'To Last until Spring 2021 and Could See $7.9 m$ Hospitalised', https://www.theguardian.com/world/2020/mar/ 15/uk-coronavirus-crisis-to-last-until-spring-2021and-could-see-79m-hospitalised (15.03.2020).

15. TST issues brief: Health and Sustainable Development, in: TST Issues Briefs. A compendium of issues briefs prepared by the United Nations inter-agency technical support team for the United Nations General Assembly Open Working Group on Sustainable Development Goals, 2014, p. 66-72.

16. WILliAMS P. D. (ed.), 2008, Security Studies. An Introduction, Routledge, London, New York, p. 5- 6.

17. WOLSKA-ZOGATA I., 2018, Psychologia spoteczna w sytuacji zagrożenia, Uniwersytet Wrocławski, Wrocław, p. 32. 
